\title{
Release of Endothelin from the Porcine Aorta Inhibition by Endothelium-derived Nitric Oxide
}

\author{
Chantal Boulanger and Thomas F. Lüscher \\ Department of Research, Laboratory of Vascular Physiology and Department of Medicine, Division of Cardiology, University Hospital, \\ CH-4031 Basel, Switzerland
}

\begin{abstract}
This study was designed to examine whether endothelin is released from the intima of intact arteries, and whether endothelium-derived nitric oxide regulates its production. Endothelin was detected in the incubating medium of unstimulated pig aortae with, but not in those without endothelium. In preparations with endothelium, thrombin $(2-6 \mathrm{U} / \mathrm{ml})$ and the calcium ionophore $\mathrm{A23187}\left(\mathrm{10}^{-6} \mathrm{M}\right)$ stimulated the release of the peptide. The basal and thrombin-stimulated production of endothelin were prevented by the protein synthetase inhibitor cycloheximide $\left(10^{-6} \mathrm{M}\right)$. The production of endothelin upon stimulation with thrombin $(4 \mathrm{U} / \mathrm{ml})$ was potentiated by $L-N^{G}$ monomethyl arginine and methylene blue and reduced by superoxide dismutase and 8-bromo cyclic guanosine 5 '-monophosphate (GMP), while the basal release of the peptide was unaffected. Thus, (a) endothelin is released from the intimal layer of intact blood vessels, both under basal conditions and after stimulation with thrombin and the calcium ionophore A23187, and (b) endothelium-derived nitric oxide released during stimulation with thrombin inhibits the production of the peptide via a cyclic GMP-dependent pathway. (J. Clin. Invest. 1990. 85:587-590.) calcium ionophore A23187 - cyclic guanosine 5'-monophosphate • endothelium-derived relaxing factor • L-arginine pathway $\bullet$ thrombin
\end{abstract}

\section{Introduction}

Endothelial cells respond to a variety of stimuli by releasing vasoactive substances such as endothelium-derived relaxing and contracting factors $(1,2)$. Endothelium-derived relaxing factor has been identified as nitric oxide formed from L-arginine in endothelial cells (3-6). Endothelin, a 21-amino acid peptide purified from the medium of cultured porcine aortic endothelial cells, is a potent endothelium-derived contracting factor $(7,8)$. The preproendothelin mRNA is expressed in the porcine aortic intima and in cultured porcine aortic endothelial cells (8). In cultured cells, the expression of the mRNA can be stimulated by thrombin, transforming growth factor beta,

Address correspondence to Dr. Thomas F. Lüscher, Department of Research and Department of Medicine, University Hospital, CH-4031 Basel, Switzerland.

Received for publication 22 September 1989.

J. Clin. Invest.

(c) The American Society for Clinical Investigation, Inc.

0021-9738/90/02/0587/04 \$2.00

Volume 85, February 1990, 587-590 epinephrine, and the calcium ionophore A23187 (8). Thrombin, arginine vasopressin, angiotensin, the calcium ionophore A23187, and phorbol esters also evoke the release of endothelin from cultured porcine and bovine endothelial cells $(9,10)$. However, it remains uncertain whether intact blood vessels can produce and release the peptide under basal conditions and during stimulation. Endothelin induces potent and longlasting contractions in vivo and in vitro $(8,11,12)$. The contractions induced by endothelin can only be fully reversed by endothelium-derived nitric oxide and nitrovasodilators, but not by other agents such as calcium antagonists $(13,14)$. Thus, endothelium-derived nitric oxide could act as the physiological antagonist of endothelin in the blood vessel wall.

The present experiments were designed to examine (a) whether endothelin is produced and released from the intact porcine aorta under basal conditions or upon stimulation with thrombin, and $(b)$ whether endothelium-derived nitric oxide regulates the production and/or release of the peptide.

\section{Methods}

Blood vessels. Aortae were obtained from farm pigs killed at the nearby slaughterhouse and placed in modified Krebs-Ringer bicarbonate solution (control solution, composition in $\mathrm{mM}: \mathrm{NaCl} 118.3, \mathrm{KCl} 4.7$, $\mathrm{CaCl}_{2} 2.5, \mathrm{MgSO}_{4} 1.2, \mathrm{KH}_{2} \mathrm{PO}_{4} 1.2, \mathrm{NaHCO}_{3}$ 25.0, Ca-EDTA 0.026, and glucose $11.1 ; \mathrm{pH}=7.4)$. The blood vessels were cleaned of connective tissue and opened longitudinally. Great care was taken to preserve the intimal surface. In some experiments the endothelial layer was rubbed mechanically.

Measurement of endothelin. The blood vessels $\left(10 \mathrm{~cm}^{2}\right.$ intimal surface) were incubated at $37^{\circ} \mathrm{C}$ in $3 \mathrm{ml}$ of control solution containing $0.1 \% \mathrm{BSA}$, aerated with a mixture of $95 \% \mathrm{O}_{2} / 5 \% \mathrm{CO}_{2}$. To study the effects of cycloheximide, $L-N^{G}$ monomethyl arginine (L-NMMA), methylene blue, SOD, or 8-bromo cyclic guanosine 5'-monophosphate (cGMP) on the production of endothelin upon stimulation with thrombin, the blood vessels were incubated for $15 \mathrm{~min}$ with the compounds before the addition of thrombin. The incubation media were collected after $4 \mathrm{~h}$ and kept frozen at $-20^{\circ} \mathrm{C}$ until use. The peptide was measured using a radioimmunoassay kit for detection of porcine or human endothelin (endothelin-1; Peninsula Laboratories, Merseyside, UK). In the experimental conditions used, the detection limit of the assay was $3 \mathrm{pg}$ immunoreactive endothelin/100 $\mu \mathrm{l}$ of sample, or $9 \mathrm{pg}$ immunoreactive endothelin $/ \mathrm{cm}^{2}$ intimal surface. For the sake of clarity, the peptide detected by radioimmunoassay (immunoreactive endothelin) will be called endothelin.

Drugs. BSA, 8-bromo cGMP, the calcium ionophore A23187, cycloheximide, SOD, and thrombin (human plasma) were purchased from Sigma Chemical Co. (St. Louis, MO). L-NMMA acetate salt was

1. Abbreviations used in this paper: cGMP, cyclic guanosine 5'-monophosphate; L-NMMA, L- $N^{\mathrm{G}}$-monomethyl arginine. 
kindly provided by Wellcome Laboratories (Beckenham, UK). D- $N^{\mathrm{G}}$ Monomethyl arginine citrate salt was purchased from Ultrafine Chemicals (Manchester, UK). Methylene blue was obtained from Merck (Zürich, Switzerland). The calcium ionophore A23187 $\left(10^{-3} \mathrm{M}\right)$ was dissolved in dimethylsulfoxide and diluted in control solution containing BSA $(0.1 \%)$ before use. $N^{G}$-Monomethyl arginine stock solutions ( $\mathrm{L}$ and $\mathrm{D}$ isomers; $2 \times 10^{-2} \mathrm{M}$ ) were obtained in distilled water, kept frozen at $-20^{\circ} \mathrm{C}$, and diluted in control solution containing BSA $(0.1 \%)$. All other drugs were dissolved in control solution containing BSA $(0.1 \%)$. All concentrations are expressed as molar concentrations in the incubation buffer.

Statistical analysis. Results are expressed as the means \pm SEM of picograms immunoreactive endothelin released per square centimeter of intimal surface after $4 \mathrm{~h}$ incubation. In all experiments $n$ is the number of pigs from which the aortae were taken. Each sample was measured in duplicate. Statistical evaluation of the data was performed using the $t$ test for paired observations and Scheffe's test for multiple comparisons. Differences were considered significant at $P<0.05$.

\section{Results}

\section{Production of endothelin}

Basal production. The basal production of endothelin by the porcine aorta was detected in preparations with, but not in those without endothelium after $4 \mathrm{~h}$ incubation $(n=3, P$ $<0.05$; Fig. 1). No detectable amounts of endothelin were observed after 1 or $2 \mathrm{~h}$ incubation. Cycloheximide $\left(10^{-6} \mathrm{M}\right)$, a protein synthetase inhibitor, markedly inhibited the basal production of endothelin, from $49 \pm 8$ to $12 \pm 7 \mathrm{pg} / \mathrm{cm}^{2}$ intimal surface $(n=4, P<0.05)$.

Thrombin. Thrombin stimulated the basal production of endothelin in a concentration-dependent manner in preparations with ( $n=7, P<0.05$; Fig. 2$)$, but not in those without endothelium ( $n=3$; amount not detectable). The effect of thrombin was maximal at $4 \mathrm{U} / \mathrm{ml}$. No detectable amount of endothelin was observed after 1 or $2 \mathrm{~h}$ stimulation with thrombin $(4 \mathrm{U} / \mathrm{ml})$. Cycloheximide $\left(10^{-6}\right)$ reduced the production of the peptide upon stimulation with thrombin $(4 \mathrm{U} / \mathrm{ml})$ from $83 \pm 10 \mathrm{pg} / \mathrm{cm}^{2}$ intimal surface, to values below the limit of detection $(n=4, P<0.05)$.

Calcium ionophore A23187. The calcium ionophore A23187 $\left(10^{-6} \mathrm{M}\right)$ stimulated the release of endothelin after $4 \mathrm{~h}$ incubation, from $30 \pm 5$ to $132 \pm 3 \mathrm{pg} / \mathrm{cm}^{2}$ intimal surface ( $n$ $=4, P<0.05)$. The calcium ionophore A23187 $\left(10^{-6} \mathrm{M}\right) \mathrm{did}$ not release detectable amounts of endothelin from preparations without endothelium $(n=3)$.

Endothelium-derived nitric oxide and production of endothelin

L-NMMA $\left(2 \times 10^{-4} \mathrm{M}\right)$ augmented the thrombin-stimulated, but not the basal release of endothelin from porcine aortae

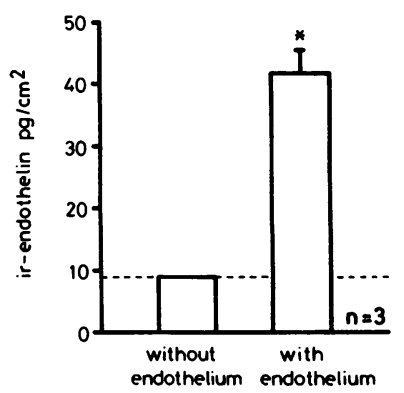

Figure 1. Basal release of endothelin from intact porcine aortae with and without endothelium $(n=3)$. The amount of endothelin produced is expressed as picograms immunoreactive (ir) endothelin per square centimeter intimal surface after $4 \mathrm{~h}$ incubation. No detectable amount of the peptide was observed in the preparations without endothelium. * Indicates a significant difference between

preparations with and without endothelium $(P<0.05)$. Dotted line represents the limit of detection of endothelin.

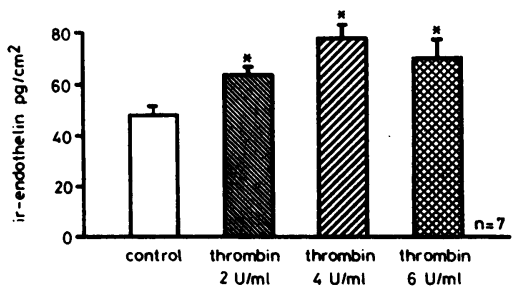

Figure 2. Stimulation of the production of endothelin by thrombin $(2-6 \mathrm{U} / \mathrm{ml})$ from porcine aortae with endothelium. The amount of endothelin produced is expressed as picograms of immunoreactive (ir) endothelin per square centimeter of intimal surface after $4 \mathrm{~h}$ incubation $(n=7)$. Thrombin (up to $8 \mathrm{U} / \mathrm{ml}$ ) did not release detectable amounts of endothelin in preparations without endothelium $(n=3)$. * Indicates a significant difference as compared with control $(P<$ 0.05).

with endothelium ( $n=8, P<0.05$; Fig. 3). D- $N^{G}$-Monomethyl arginine $\left(2 \times 10^{-4} \mathrm{M}\right)$ did not modify the basal and thrombinstimulated production of endothelin ( $n=4$; data not shown). Methylene blue $\left(10^{-5} \mathrm{M}\right)$ did not significantly modify the basal production of endothelin; however, it stimulated that induced by thrombin $(4 \mathrm{U} / \mathrm{ml})(n=6, P<0.05$; Fig. 4). SOD (250 $\mathrm{U} / \mathrm{ml}$ ) did not influence the basal production of the peptide (control, $41 \pm 7$; SOD, $31 \pm 9 \mathrm{pg} / \mathrm{cm}^{2}$ intimal surface; $n=6$ ), but inhibited that upon stimulation with thrombin $(4 \mathrm{U} / \mathrm{ml})(n$ $=6, P<0.05$; Fig. 5). Similarly, 8-bromo cGMP $\left(10^{-3} \mathrm{M}\right)$ did not affect the basal release of endothelin (control, $44 \pm 3.5$; 8-bromo cGMP, $50 \pm 3 \mathrm{pg} / \mathrm{cm}^{2}$ intimal surface; $n=6$ ), but decreased the production of the peptide upon stimulation with thrombin $(4 \mathrm{U} / \mathrm{ml})(n=6, P<0.05$; Fig. 5$)$.

\section{Discussion}

The present experiments demonstrate that endothelin is released not only from cultured cells, but also from intact blood vessels in an endothelium-dependent manner. The peptide is produced both under basal conditions and after stimulation with thrombin or the calcium ionophore A23187. Endothelium-derived nitric oxide inhibits the formation of endothelin via a cGMP-dependent mechanism.

The fact that the production of endothelin is endothelium dependent is in agreement with the expression of preproendothelin mRNA in cultured porcine endothelial cells, but not in cultured porcine vascular smooth muscle cells (8). The expression of preproendothelin mRNA has also been observed in the intimal layer of the pig aorta (8). This study demonstrates that endothelin is indeed released under basal conditions from the intact aorta of the pig, and can be stimulated by thrombin and the calcium ionophore A23187. The production of the

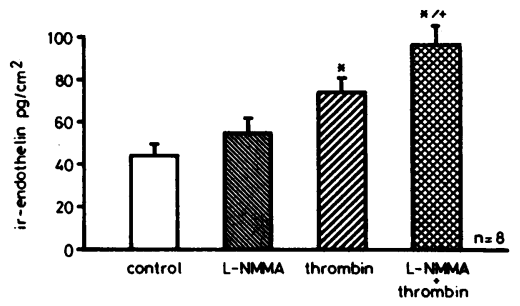

Figure 3. Effect of LNMMA $\left(2 \times 10^{-4} \mathrm{M}\right)$ on the production of endothelin under basal conditions and upon stimulation with thrombin $(4 \mathrm{U} / \mathrm{ml})$ in porcine aortae with endothelium. The amount of peptide produced is expressed as picograms immunoreactive (ir) endothelin released per square centimeter intimal surface after $4 \mathrm{~h}$ incubation $(n=8)$. $*$ Indicates a significant difference as compared with control; + indicates a significant difference of preparations stimulated with thrombin in the presence and absence of L-NMMA $(P<0.05)$. 


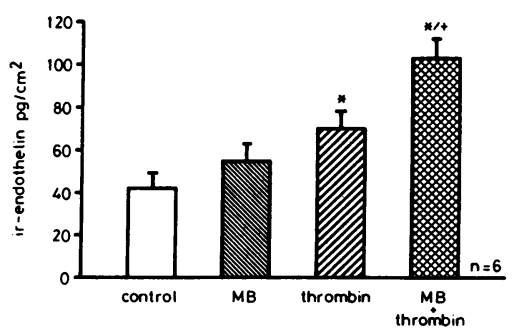

Figure 4. Effect of methylene blue $(M B$; $\left.10^{-5} \mathrm{M}\right)$ on the release of endothelin from porcine aortae with endothelium under basal conditions (control) and upon stimulation with thrombin $(4 \mathrm{U} / \mathrm{ml} ; \boldsymbol{n}$ $=6$ ). The amount of peptide produced is expressed as picograms immunoreactive (ir) endothelin released per square centimeter intimal surface after $4 \mathrm{~h}$ incubation. * Indicates a significant difference as compared with control; + indicates a significant difference of preparations stimulated with thrombin in the presence and absence of methylene blue ( $P$ $<0.05)$.

peptide requires de novo protein synthesis, since the protein synthetase inhibitor cycloheximide markedly inhibited the release of the peptide in control and thrombin-stimulated preparations. The time course of the production of endothelin induced by thrombin in the porcine aorta also is compatible with a stimulation of the production of the peptide rather than its release from intracellular stores (8).

Thrombin not only stimulates the production of endothelin, but also releases endothelium-derived relaxing factor in a variety of blood vessels (15-18). Endothelium-derived relaxing factor has been identified as nitric oxide (3-5); the amino acid L-arginine is the precursor of nitric oxide in endothelial cells (6). The production of nitric oxide from cultured endothelial cells and from the endothelium of isolated blood vessels can be inhibited stereospecifically by L-NMMA, which is a false substrate for the enzyme synthesizing nitric oxide $(6,19)$. Nitric oxide activates soluble guanylate cyclase and in turn increases cGMP levels in endothelial and vascular smooth muscle cells (20-24). In the porcine aorta, the production of endothelin upon stimulation with thrombin was potentiated by L-NMMA and by methylene blue, an inhibitor of soluble guanylate cyclase $(25,26)$. In addition, SOD, a scavenger of superoxide anions that inactivate endothelium-derived nitric oxide $(27$, 28 ), and 8-bromo cGMP, a nonhydrolyzable analogue of cGMP, reduced the production of endothelin induced by thrombin. These results indicate that during stimulation with thrombin, endothelium-derived nitric oxide inhibits the production of endothelin. The inhibitory effects of nitric oxide on the production of endothelin must be mediated by a cGMPdependent pathway, since the inhibitor of soluble guanylate cyclase methylene blue increased, and the nonhydrolyzable

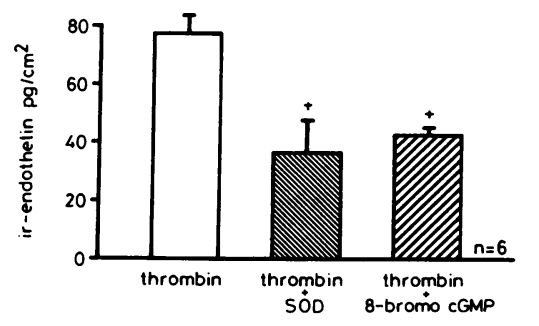

Figure 5. Effect of SOD $(250 \mathrm{U} / \mathrm{ml})$ and 8 bromo cGMP $\left(10^{-3} \mathrm{M}\right)$ on the production of endothelin induced by thrombin $(4 \mathrm{U} / \mathrm{ml})$ in porcine aortae with endothelium $(n=6)$. The amount of peptide produced is expressed as

picograms immunoreactive (ir) endothelin released per square centimeter intimal surface after $4 \mathrm{~h}$ incubation. + Indicates a significant effect of SOD and 8-bromo cGMP on the response to thrombin $(P<$ 0.05). analogue of CGMP lowered the thrombin-stimulated production of the peptide.

In contrast, the basal production of endothelin was not affected by L-NMMA, methylene blue, SOD, or 8-bromo cGMP. This suggests that under basal conditions very little endothelium-derived nitric oxide is produced, or that a relaxing factor different from nitric oxide is released. The latter interpretation is in line with the fact that in perfused cultured porcine aortic endothelial cells nitric oxide does not account for endothelium-dependent relaxations occurring under basal conditions (29). The inability of 8-bromo cGMP to inhibit the basal production of endothelin further indicates that the spontaneous formation of the peptide is insensitive to modulation by endothelium-derived nitric oxide. This explanation is reinforced by the fact that the thrombin-induced production of endothelin could not be inhibited by SOD or by 8 -bromo cGMP to a level below the amount of peptide released under control conditions.

The inhibition of the production of endothelin by endothelium-derived nitric oxide might have important physiological and pathophysiological implications. Endothelium-derived nitric oxide plays a major role in the regulation of vascular tone and platelet function (1, 30-33); besides its direct effects on smooth muscle, the inhibitory effects of endothelium-derived nitric oxide on the endothelin production represent a new mechanism of action whereby the endogenous nitrate can affect vascular tone. In arteries with regenerated endothelium, hyperlipidemia, hypertension, and atherosclerosis, the release of endothelium-derived nitric oxide is impaired (34-38). An impaired release of endothelium-derived nitric oxide in diseased arteries may lead to an enhanced endothelin production. The reduced release of endothelium-derived nitric oxide favors local platelet activation $(32,33,35,39)$. Thrombin and transforming growth factor beta, which are abundantly present under these conditions $(40,41)$, would stimulate the production of endothelin, unopposed by the endogenous nitric oxide. This may contribute importantly to the occurrence of spasm in diseased blood vessels.

\section{Acknowledgments}

The authors wish to thank Dr. Salvador Moncada (Wellcome Laboratories, Beckenham, UK) for the gift of L-NMMA, and Bernadette Libsig for drawing the figures.

This work was supported by grants from the Swiss National Research Foundation (3.889-0.86 and 32-25468.88), the Swiss Foundation of Cardiology, and the Schweizerische Rentenanstalt. Dr. Lüscher is a recipient of a career development award of the Swiss National Research Foundation (SCORE grant 3231-025150).

\section{References}

1. Furchgott, R. F., and P. M. Vanhoutte. 1989. Endothelium-derived relaxing and contracting factors. FASEB (Fed. Am. Soc. Exp. Biol.) J. 3:2007-2019.

2. Lüscher, T. F. 1988. Endothelial vasoactive substances and cardiovascular disease. Karger A. G., Basel, Switzerland. 133 pp.

3. Furchgott, R. F. 1988. Studies on relaxation of rabbit aorta by sodium nitrite: the basis for the proposal that the acid-activatable inhibitory factor from bovine retractor penis is inorganic nitrite and the endothelium-derived relaxing factor is nitric oxide. In Vasodilatation. P. M. Vanhoutte, editor. Raven Press, New York. 401-414.

4. Ignarro, L. J., R. E. Byrns, G. M. Buga, K. S. Wood, and G. Chaudhuri. 1988. Pharmacological evidence that endothelium-derived relaxing factor is nitric oxide: use of pyrogallol and superoxide dismu- 
tase to study endothelium-dependent and nitric oxide-elicited vascular smooth muscle relaxation. J. Pharmacol. Exp. Ther. 244:181-189.

5. Palmer, R. M. J., A. G. Ferrige, and S. Moncada. 1987. Nitric oxide release accounts for the biological activity of endothelium-derived relaxing factor. Nature (Lond.). 327:524-526.

6. Palmer, R. M. J., D. S. Ashton, and S. Moncada. 1988. Vascular endothelial cells synthesize nitric oxide from L-arginine. Nature (Lond.). 333:664-666.

7. Hickey, K. A., G. Rubanyi, R. J. Paul, and R. F. Highsmith. 1985. Characterization of a coronary vasoconstrictor produced by cultured endothelial cells. Am. J. Physiol. 248:C550-C556.

8. Yanagisawa, M., H. Kurihara, S. Kimura, Y. Tomobe, M. Kabayashi, Y. Mitsui, Y. Yasaki, K. Goto, and T. Masaki. 1988. A novel potent vasoconstrictor peptide produced by vascular endothelial cells. Nature (Lond.). 332:411-415

9. Emori, T., Y. Hirata, K. Ohta, M. Shichiri, and F. Marumo. 1989. Secretory mechanism of immunoreactive endothelin in cultured bovine endothelial cells. Biochem. Biophys. Res. Commun. 160:93100.

10. Schini, V. B., H. Hendrickson, D. M. Heublein, J. C. Burnett Jr., and P. M. Vanhoutte. 1989. Thrombin enhances the release of endothelin from cultured porcine aortic endothelial cells. Eur. J. Pharmacol. 165:333-334.

11. Tomobe, Y., T. Miyauchi, A. Saito, M. Yanagisawa, S. Kimura, K. Goto, and T. Masaki. 1988. Effect of endothelin on the renal artery from spontaneously hypertensive and Wistar Kyoto rats. Eur. J. Pharmacol. 152:373-374.

12. D’Orleans-Juste, P., M. Finet, G. de Nucci, and J. R. Vane. 1989. Pharmacology of endothelin-1 in isolated vessels: effect of nicardipine, methylene blue, hemoglobin and gossypol. J. Cardiovasc. Pharmacol. 13:S19-S22.

13. Vanhoutte, P. M., W. Auch-Schwelk, C. Boulanger, P. A. Janssen, Z. S. Katusic, K. Komori, V. M. Miller, V. B. Schini, and M. Vidal. 1989. Does endothelin-1 mediate endothelium-dependent contractions during anoxia? J. Cardiovasc. Pharmacol. 13:S124-S128.

14. Yang, Z., F. R. Bühler, D. Diederich, and T. F. Lüscher. 1989. Different effects of endothelin-1 on cAMP and cGMP mediated vascular relaxation in human arteries and veins: comparison with norepinephrine. J. Cardiovasc. Pharmacol. 13:S129-S131.

15. De Mey, J. G., M. Claeys, and P. M. Vanhoutte. 1982. Endothelium-dependent inhibitory effects of acetylcholine, adenosine diphosphate, thrombin and arachidonic acid in the canine femoral artery. J. Pharmacol. Exp. Ther. 222:166-173.

16. De Mey, J. G., and P. M. Vanhoutte. 1982. Heterogenous behavior of the canine arterial and venous wall: importance of the endothelium. Circ. Res. 51:439-447.

17. Rapoport, R.M., M. B. Draznin, and F. Murad. 1984. Mechanisms of the adenosine triphosphate-, thrombin- and trypsin-induced relaxation of rat thoracic aorta. Circ. Res. 55:468-479.

18. Lüscher, T. F., D. Diederich, R. Siebenmann, K. Lehmann, P. Stulz, L. von Segesser, Z. Yang, M. Turina, E. Grädel, E. Weber, and F. R. Bühler. 1988. Differences between endothelium-dependent relaxation in arterial and in venous coronary bypass grafts. $N$. Engl. J. Med. 319:462-467.

19. Rees, D. D., R. M. J. Palmer, H. F. Hodson, and S. Moncada. 1989. A specific inhibitor of nitric oxide formation from $L$-arginine attenuates endothelium-dependent relaxations. Br. J. Pharmacol. 96:418-424.

20. Rapoport, R. M., and F. Murad. 1983. Agonist-induced endothelium-dependent relaxation in rat thoracic aorta may be mediated through cGMP. Circ. Res. 52:352-357.

21. Martin, W., D. G. White, and A. H. Henderson. 1988. Endothelium-derived relaxing factor and atriopeptin II elevate cyclic GMP levels in pig aortic endothelial cells. Br. J. Pharmacol. 93:229-239.

22. Ignarro, L. J., R. G. Harbison, K. S. Wood, and P. J. Kadowitz. 1986. Activation of purified soluble guanylate cyclase by endothelium-derived relaxing factor from intrapulmonary artery and vein: stimulation by acetylcholine, bradykinin, and arachidonic acid. $J$. Pharmacol. Exp. Ther. 237:893-900.

23. Arnold, W. P., C. K. Mittal, S. Katsuki, and F. Murad. 1977. Nitric oxide activates soluble guanylate cyclase and increases guanosine $3^{\prime}: 5^{\prime}$-cyclic monophosphate in various tissue preparations. Proc. Natl. Acad. Sci. USA. 74:3203-3207.

24. Boulanger, C., V. B. Schini, and P. M. Vanhoutte. 1989. Production of cyclic GMP by bradykinin, adenosine diphosphate, the calcium ionophore $\mathrm{A} 23187$ and nitric oxide in cultured porcine aortic endothelial cells. FASEB (Fed. Am. Soc. Exp. Biol.) J. 3:A533. (Abstr.)

25. Gruetter, C. A., D. Y. Gruetter, J. E. Lyon, P. J. Kadowitz, and L. J. Ignarro. 1981. Relationship between cyclic guanosine monophosphate formation and relaxation of coronary arterial smooth muscle by glyceryl trinitrate, nitroprusside, nitrite, and nitrite oxide: effects of methylene blue and methemoglobin. J. Pharmacol. Exp. Ther. 219:181-186.

26. Martin, W., G. M. Villani, D. Jothianandan, and R. F. Furchgott. 1985. Selective blockade of endothelium-dependent and glyceryl trinitrate-induced relaxation by hemoglobin and by methylene blue in the rabbit aorta. J. Pharmacol. Exp. Ther. 233:679-685.

27. Rubanyi, G. M., and P. M. Vanhoutte. 1986. Superoxide anions and hyperoxia inactivate endothelium-derived relaxing factor. Am. J. Physiol. 250:H822-H827.

28. Gryglewski, R. J., R. M. J. Palmer, and S. Moncada. 1986. Superoxide anion is involved in the breakdown of endothelium-derived vascular relaxing factor. Nature (Lond.). 320:454-456.

29. Boulanger, C., H. Hendrickson, R. R. Lorenz, and P. M. Vanhoutte. 1989. Release of different relaxing factors by cultured porcine endothelial cells. Circ. Res. 64:1070-1078.

30. Moncada, S., M. W. Radomski, and R. M. J. Palmer. 1988. Endothelium-derived relaxing factor: identification as nitric oxide and role in the control of vascular tone and platelet function. Biochem. Pharmacol. 37:2495-2501.

31. Radomski, M. W., R. M. J. Palmer, and S. Moncada. 1987. The anti-aggregating properties of vascular endothelium: interactions between prostacyclin and nitric oxide. Br. J. Pharmacol. 92:639-646.

32. Radomski, M. W., R. M. J. Palmer, and S. Moncada. 1987. Endogenous nitric oxide inhibits human platelet adhesion to vascular endothelium. Lancet. ii: 1057-1068.

33. Sneddon, J. M., and J. R. Vane. 1988. Endothelium-derived relaxing factor reduces platelet adhesion to bovine endothelial cells. Proc. Natl. Acad. Sci. USA. 85:2800-2804.

34. Lüscher, T. F. 1989. Endothelium-derived relaxing and contracting factors: potential role in coronary artery disease. Eur. Heart J. 10:847-857.

35. Shimokawa, H., L. L. Aarhus, and P. M. Vanhoutte. 1987. Porcine coronary arteries with regenerated endothelium have a reduced endothelium-dependent responsiveness to aggregating platelets and serotonin. Circ. Res. 61:256-270.

36. Shimokawa, H., and P. M. Vanhoutte. 1989. Impaired endothelium-dependent relaxation to aggregating platelets and related vasoactive substances in porcine coronary arteries in hypercholesterolemia and in atherosclerosis. Circ. Res. 64:900-914.

37. Boulanger, C., F. R. Bühler, and T. F. Lüscher. 1989. Native low-density lipoproteins impair the release of relaxing factors from cultured porcine endothelial cells. Eur. Heart J. 10:A1883. (Abstr.)

38. Lüscher, T. F., L. Raij, and P. M. Vanhoutte. 1987. Endothelium-dependent responses in normotensive and hypertensive Dahl rats. Hypertension (Dallas). 9:157-163.

39. Vanhoutte, P. M., and D. S. Houston. 1985. Platelets, endothelium and vasospasm. Circulation 72:728-734.

40. Shuman, M. A., and P. W. Majerus. 1976. The measurement of thrombin in clotting blood by radioimmunoassay. J. Clin. Invest. 58:1249-1253.

41. Assoian, R. K., A. Komoriya, C. A. Meyers, D. M. Miller, and M. B. Sporn. 1983. Transforming growth factor- $\beta$ in human platelets. J. Biol. Chem. 258:7155-7160. 